\title{
Dendritic microborings in brachiopod shells from the Silurian of the Barrandian area, Czech Republic
}

\author{
Michal Mergl
}

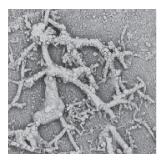

\begin{abstract}
Four types of dendritic microborings preserved as natural casts were observed on the surfaces of brachiopod shells from the Silurian in Central Bohemia: Rhopalondendrina jakubinka isp. nov., ? Clionolithes isp., and an indeterminate dendrinid are of Llandovery (Aeronian) age, Clionolithes amoebae isp. nov. is of Ludlow (Gorstian) age. Rhopalondendrina jakubinka forms a dense plexus of thin rhizoidal tunnels extending from a broad and curved entrance tunnel. ? Clionolithes isp. forms characteristically rarely branching thin meandering tunnels with a globular central node, while $C$. amoebae forms rosette-like microborings with sinuously curved primary branches and scarce lateral branches of smaller size. Microborings are present both on outer and inner surfaces of shells; their location and number confirm massive infestation of dead shells which were exposed on the sea floor for long time intervals and which were not affected by mechanical abrasion of the shells. This indicates narrow ecological limits for these endobionts, most likely within the deeper euphotic zone. - Key words: bioerosion, endobiont, dendrinids, Aeronian, Gorstian, Silurian, Barrandian.
\end{abstract}

Mergl, M. 2020. Dendritic microborings in brachiopod shells from the Silurian of the Barrandian area, Czech Republic. Bulletin of Geosciences 95(3), 319-332 (6 figures). Czech Geological Survey, Prague. ISSN 1214-1119. Manuscript received April 9, 2020; accepted in revised form July 22, 2020; published online August 9, 2020; issued August 9, 2020.

Michal Mergl, Centre of Biology, Geosciences and Environmental Sciences, Faculty of Education, University of West Bohemia, Klatovská 51,30619, Plzen̆,Czech Republic; mmergl@cbg.zcu.cz

Dendritic and/or rosette-like microborings in calcareous and phosphatic skeletal substrates have a long geological history, spanning most of the Phanerozoic. Wisshak (2017) distinguished seven ichnogenera and twenty-two ichnospecies in his updated survey of the ichnofamily Dendrinidae. Their most prominent occurrences are in Devonian brachiopod shells and Upper Cretaceous belemnite guards. Wisshak listed the dendrinid ichnogenera Dictyoporus Mägdefrau, 1937, Nododendrina Vogel et al., 1987, Pyrodendrina Tapanila, 2008 from the Ordovician, and the additional ichnogenera Clionolithes Clarke, 1908 and Dendrina Quenstedt, 1849 from the Silurian. The genus Clionolithes is no doubt the most widespread Palaeozoic dendrinid with an early fossil record from the Upper Ordovician of the Cincinnati Arch region, USA (Vogel \& Brett 2009, Dendroid Form 2, fig. 30) and Ordovician and Silurian of Estonia (Toom et al. 2019). More microborings assigned or related to Clionolithes occur in the Middle and Upper Devonian (Clarke 1908, 1921; Solle 1938; Fenton \& Fenton 1932; Talent 1963; Vogel et al. 1987; Furlong $\&$ McRoberts 2014; Wisshak 2017). The genus has its last record in the Upper Cretaceous (Hofmann 1996).

Clionolithes and similar dendritic ichnospecies preserved on brachiopod shells of Silurian age have not been observed previously in the Barrandian area. Hence, this paper describes and illustrates finely preserved natural casts of dendrinids associated with brachiopods in the Želkovice and Kopanina formations.

\section{Geological setting}

Shelly fossil associations with preserved natural casts of dendritic microborings have been observed in two localities with the Silurian rocks in the Barrandian area of the Czech Republic (Fig. 1). For the geological setting and detailed overviews of these localities, see the publications of Havlíček \& Kříž (1973) and Kříž (1991, 1992, 1998).

Locality 1: "V Jakubince" Valley between Hýskov and Železná villages (GPS 50 00' 14.1" N, 14 $04^{\circ} 15.6^{\prime \prime} \mathrm{E}$ ), in a wedged tectonic block of sediments and volcanites of Llandovery age. The large tectonic block of the Želkovice Formation is preserved within the zone of the Prague Fault. The locality was discovered by Havlíček \& Kř́iž (1973) and was the subject of intensive palaeontological exploration during the last decades. Fossiliferous beds have been accessible only in artificial excavations; of these, test-pit DB 226 (by Štorch 2001) yielded shells bearing the dendritic microborings.

The volcano-sedimentary sequence of the Želkovice Formation is represented by tectonically disturbed basalts 
with hyaloclastites that are followed by calcareous tuffites, tuffaceous limestones, tuffaceous and calcareous shales. The shales have yielded a rich fauna of late Aeronian age (Stimulograptus sedgwickii graptolite Biozone; Štorch 2001; Conochitina alargada chitinozoan Biozone, Tonarová et al. 2019), with 13 graptolite species (Štorch 2001), 26 trilobite species (Šnajdr 1975, 1978), 30 brachiopod species (Havlíček 1977; Havlíček \& Štorch 1990; Mergl 1999, 2001), 13 species of dendroid graptolites (Kraft 1982), 20 polychaete taxa (Tonarová et al. 2019) and so far unrevised gastropods, corals and other invertebrate groups. Acritarchs, chitinozoans and conodonts were studied by Dufka $(1990,1992)$ and Tonarová et al. (2019). The depositional environment was described by Krríž (1991) and Tonarová et al. (2019) and interpreted as well-ventilated, shallow water, agitated flats on effusive and volcanoclastic sediments of the Hýskov Volcanic Centre. The rich benthic shelly fauna observed here is unique in the Barrandian area, because in other localities of the Želkovice Formation only planktonic and/ or epiplanktonic forms are present.

Dendritic microborings were observed in weakly weathered, laminated tuffaceous shale which is rich in broken brachiopod shells of the pentamerid Stricklandia sp., the orthids Saukrodictya arcana Havlíček, 1977 and Giraldibella hyskovensis Havlíček, 1977, the plectambonitid Aegironetes lunulla Havlíček, 1990 in Havlíček \& Štorch (1990), and the athyrid Hindella sp. as well as the trilobites Encrinuraspis mareki Šnajdr, 1975 associated with Leonaspis orphana Šnajdr, 1975 and other minute trilobites. Fragments of pelagic graptolites and chitinozoans show a mass occurrence in shale. A different dendritic microboring was observed on a single shell of Triplesia eospiriferoides Havlíček, 1990 in Havlíček \& Štorch (1990), which was sampled in tuffaceous limestone higher in the section. It likely came from a shallower environment which yielded, among other fossils, favositid tabulates.

Locality 2: Kosov Quarry Section near Králův Dvůr, locality No. 776 of Kř́žž (1992) (GPS 49 56' 27.4" N, 14 $03^{\prime} 20.1^{\prime \prime}$ E). The upper part of the Kopanina Formation tuffaceous facies (Ludlowian, Gorstian) is exposed in this outcrop behind the demolished former canteen of the quarry. Tuffaceous shale is overlain by light-grey bioclastic limestone and several beds of massive brownish tuffites. The section is described in detail by Kř́žz (1992). The lowest fossil association is characterised by abundant brachiopods, fragmented cephalopods and the trilobite Balizoma transiens (Barrande, 1852). A different and more diverse fauna occurs higher in the section, typically with the trilobite Encrinuraspis beaumonti (Barrande, 1846) and the pentamerid Bleshidium patellinum (Barrande, 1879) (Kříž 1992, Havlíček 1995, Havlíček \& Štorch 1990).
Dendritic microborings were observed in the lowest beds of decalcified tuffaceous shale, in association with abundant disarticulated brachiopod shells. Among the brachiopods, the strophomenid Leptostrophiella nebulosa (Barrande, 1848), the pentamerid Jonesea myrmido (Barrande, 1879), the atrypid Kantinatrypa gambrina Havlíček, 1995, and the spiriferids Cyrtia bedya Havlíček, 1990 in Havlíček \& Štorch (1990), Tenellodermis tenellus (Barrande, 1848) and Janius bouskai Havlíček, 1980 are characteristic species of this association. Small orthids and rhynchonellids are rarely present. Fragments of cephalopod shells, a graptolite referred by Kř́žz (1992) to Monograptus massai Jaeger, 1991, and scarce other fauna co-occur with the brachiopods. The association has been referred to the Lobograptus scanicus/Saetograptus chimaera graptolite Biozone of late Gorstian age (Havlíček 1995, Loydell 2012). The depositional environment was described by Kř́iž (1992) as an agitated shallow marine site on effusive and volcanoclastic sediments of the Kosov Volcanic Centre.

\section{Material and methods}

All microborings are preserved as natural casts attached to external or internal moulds of brachiopod shells and trilobite shields. The original calcareous shells were naturally removed by weathering processes, leaving the original mudstone infills of the microborings. The surface of some casts is covered by a fine limonitic film that may obscure small details. Mode of preservation rules out the use of resin for making artificial casts or of micro-CT, which are now methods widely used in investigation of shell microborings (Wisshak 2017, Wisshak et al. 2017).

Selected specimens were photographed with an OLYMPUS SZX7 microscope, some using Deep focus technology. The surfaces of some natural cast were whitened with ammonium chloride to increase the silhouette of the cast, but this method also accentuated the original granularity of the clay infill and structure of the limonite coats. Electron microscopy was avoided because of the large size of the shale slabs with the bored shells.

Repository: All specimens are housed in the palaeontological collections of the Centre of Biology, Earth and Environmental Sciences in the Faculty of Education of the University of West Bohemia in Plzen (PCZCU), the Czech Republic.

\section{Systematic palaeontology}

Ichnofamily Dendrinidae Bromley, Wisshak, Gloub \& Botquelen, 2007 


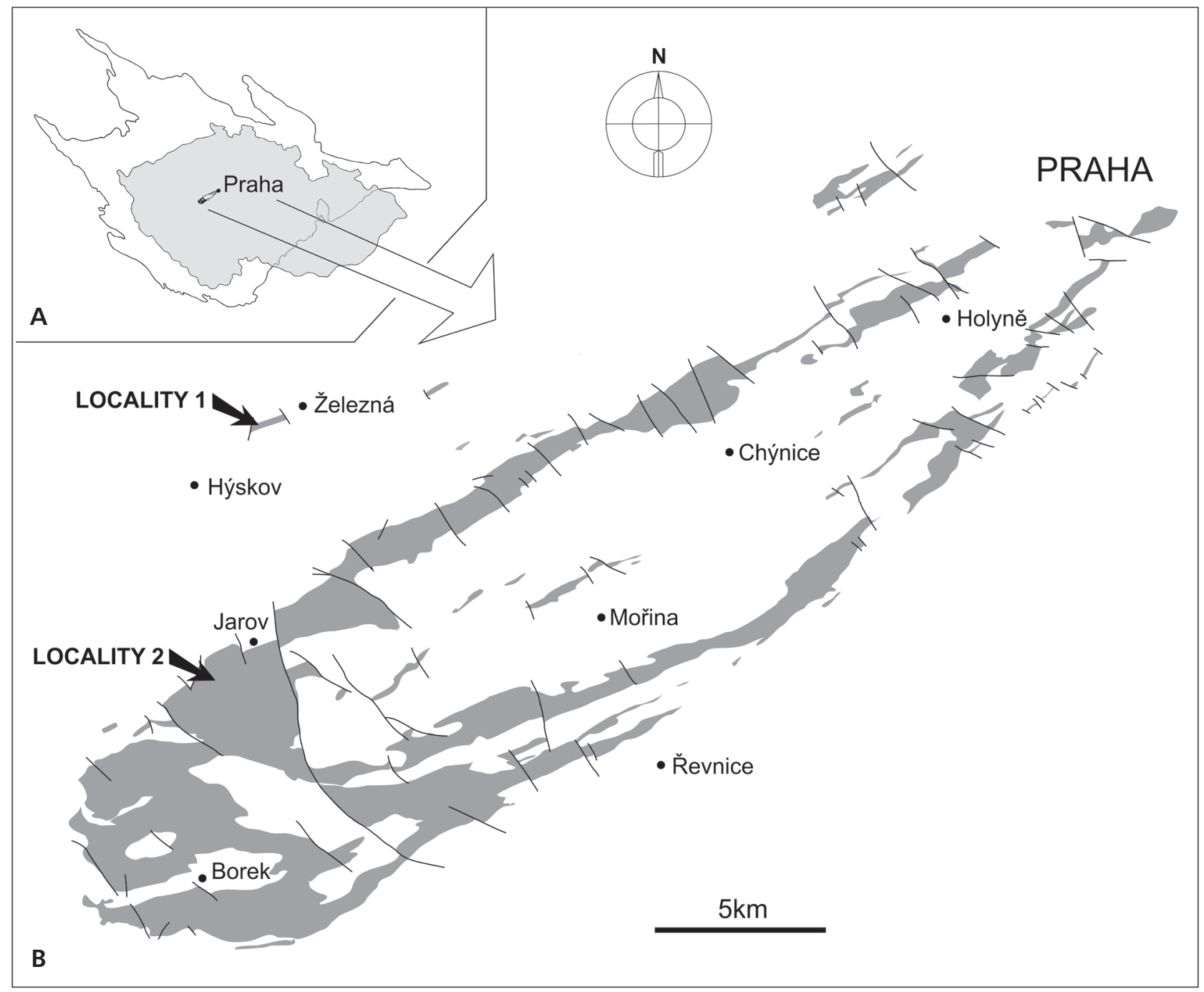

Figure 1. Schematic location maps showing the Czech Republic (A) and the distribution of Silurian outcrops with positions of sampled localities (B).

\section{Ichnogenus Clionolithes Clarke, 1908}

Type ichnospecies. - Clionolithes radicans Clarke, 1908; Upper Devonian, Chemung Group; Pennsylvania, USA.

\section{Clionolithes amoebae isp. nov.}

Figure 2

Types. - Holotype: PCZCU 2403, a natural cast attached to the surface of an external mould of the spiriferide brachiopod Cyrtia bedya Havlíček, 1990 in Havlíček \& Štorch (1990), illustrated here in Fig. 2C.

Paratypes: PCZCU 2404, natural casts attached to the surface of an external mould of the atrypid brachiopod Kantinatrypa gambrina Havlíček, 1995, illustrated here in Fig. 2D, F, and PCZCU 2406 attached to the brachiopod shell fragment illustrated here in Fig. 2 (lower specimen).
Type horizon and locality. - Silurian, Gorstian, Kopanina Formation, Lobograptus scanicus/Saetograptus chimaera graptolite Biozone; Kosov Quarry, locality 776 after Krríž (1992), Králův Dvůr, Central Bohemia.

Material. - Five shale slabs with bored shells; figured specimens PCZCU 2403-2407.

Etymology. - Based on the shape which is reminiscent of the protozoan Amoeba.

Diagnosis. - Rosette shaped shallow microboring with indistinct to large shallow lobate central node, long sinuously curved primary branches of rounded cross sections, and sparse secondary and tertiary branches tapering towards their pointed ends; plexus with broad and sparsely anastomosing branches. 
Description. - Overall shape is rosette-like, with four, five or rarely even more primary branches extending over an area of about $1-3 \mathrm{~mm}^{2}$ (Fig. 2B, C, I), but some microborings significantly departing from a radial shape when tracking the a course of linear structures of brachiopod shells such as ribs or concentric lamellae (Fig. $2 \mathrm{H}, \mathrm{F})$.

The primary branches extend from the central node which can be initially inconspicuous and as wide as the proximal parts of the extending primary branches (Fig. 2C) but the node may enlarge into an extensive lobate shape with a shallow and weakly excavated floor (Fig. 2L). The central node may reach $500 \mu \mathrm{m}$ in diameter (Fig. 2L). The plexus of particular branches may be simple (Fig. 2C, I) to very complex with anastomosing tunnels of adjoining microborings (Fig. 2G, L). Branching style varies in density, angle and form of anastomoses. Primary and secondary branches are sinuously curved having circular to high-oval cross sections and smooth surfaces, although the finest details of surface may be obscured by the granularity of the natural sediment infill. Secondary and tertiary branches are shorter and narrower than primary branches, and they slowly to rapidly taper toward their pointed ends (Fig. 2F). In a simple examined microboring (Fig. 2B, C, I), the angle of divergence of the secondary branches is near to $90^{\circ}$, while the angles of branching significantly vary in other more complex plexuses (Fig. 2K, L).

Remarks. - The new ichnospecies is referred to Clionolithes due to the overall shape of the microboring forming rosette excavations and tunnels in the uppermost part of the shell substrate. The type species Clionolithes radicans (Clarke, 1908) from the Upper Devonian of Pennsylvania, USA, is generally similar but differs by its straight and only slightly arcuate primary branches which are deeper and narrowly excavated in cross section. The type specimen was figured by Furlong \& McRoberts (2014) and the profile of the tunnels have been illustrated by Wisshak (2017, fig. 5f). The primary branches of C. amoebae isp. nov. are sinuously curved, rounded to oval in cross section, and their branching is sparse. The secondary or tertiary branches are shorter and diverge at a greater angle than those of $C$. radicans. The tips of the terminal branches are acute in C. amoebae. These differences indicate a deeper penetration into the shell substance in $C$. radicans than C. amoebae. This is evident also from relatively large but shallow central node of $C$. amoebae. The central node and plexus of $C$. amoebae never perforate the shell. As shown in the thin shells of the strophomenid Leptostrophiella nebulosa, the central node and plexus may be very shallow (Fig. 2J, K).

There are several Devonian species of microborings of similar form and size to the new ichnospecies. Clionolithes palmatus Clarke, 1908 from the Upper Devonian of the USA, differs from C. amoebae by the presence of sheetlike and laterally widening fans of branches. Clionolithes cervicormis (Vogel, Golubic \& Brett, 1987) from the Middle Devonian of New York, USA, differs by its dense branching, with the branches being of almost equal width. Clionolithes alciformis (Vogel, Golubic \& Brett, 1987) of the same provenance is distinguished by its short primary branches and numerous secondary branches rapidly tapering toward their ends. Clionolithes pannosus (Solle, 1938) from the Emsian of Germany has much shorter and wider branches without sinusoid course and different type of branching. Vogel \& Brett (2009, p. 15, fig. 30) described and figured a formally unnamed dendritic form of microboring from the Upper Ordovician of Arch region, USA which in size, the sinusoidal shape of the primary branches and the sparse branching is similar to the new ichnospecies. This Ordovician microboring they compared to Clionolithes cervicornis but this Devonian ichnospecies differs in its dense plexus of equally wide secondary branches, as stated by the authors.

Occurrence. - The type locality only.

\section{? Clionolithes isp.}

Figure 3

Material. - One specimen of the brachiopod Stricklandia sp. with two microborings and one of the brachiopod Hindella sp. with more than 10 microborings, all preserved as natural casts; figured specimens PCZCU 2409-, PCZCU $2015 \mathrm{c}-\mathrm{h}$.

Description. - Microboring has the shape of long thin primary branch extending from an approximately 150 $\mu \mathrm{m}$-sized globose deep central node. Usually, only one

Figure 2. Clionolithes amoebae isp. nov.; Kopanina Formation; Kosov Quarry, locality No. 775; A-C - PCZCU 2403, the holotype (A), external mould of shell of Cyrtia bedya with two natural casts on fold and left flank of the dorsal valve, and (B) detail of the cast on flank, and (C) detail of the cast on fold; D-F, H - PCZCU 2404, external mould of moderately bored (D) dorsal valve of Kantinatrypa gambrina with (E) two small microborings aligned along growth lamellae, (F) small specimen near growth lamellae, and (H) elongate specimen tracing a rib of the shell; G, L - PCZCU 2405, external mould of heavily bored $(\mathrm{G})$ dorsal valve of Kantinatrypa gambrina with (L) several specimens showing anastomosing plexus; I - PCZCU 2406, four natural casts on fragment of unidentified brachiopod shell, note sinusoid proximal branches; J - PCZCU 2407, external mould of bored (G) ventral valve of Leptostrophiella nebulosa; and $\mathrm{K}$ - detail of densely branched plexus. All specimens are coated by ammonium chloride. Scale bars equal to 1 mm. 


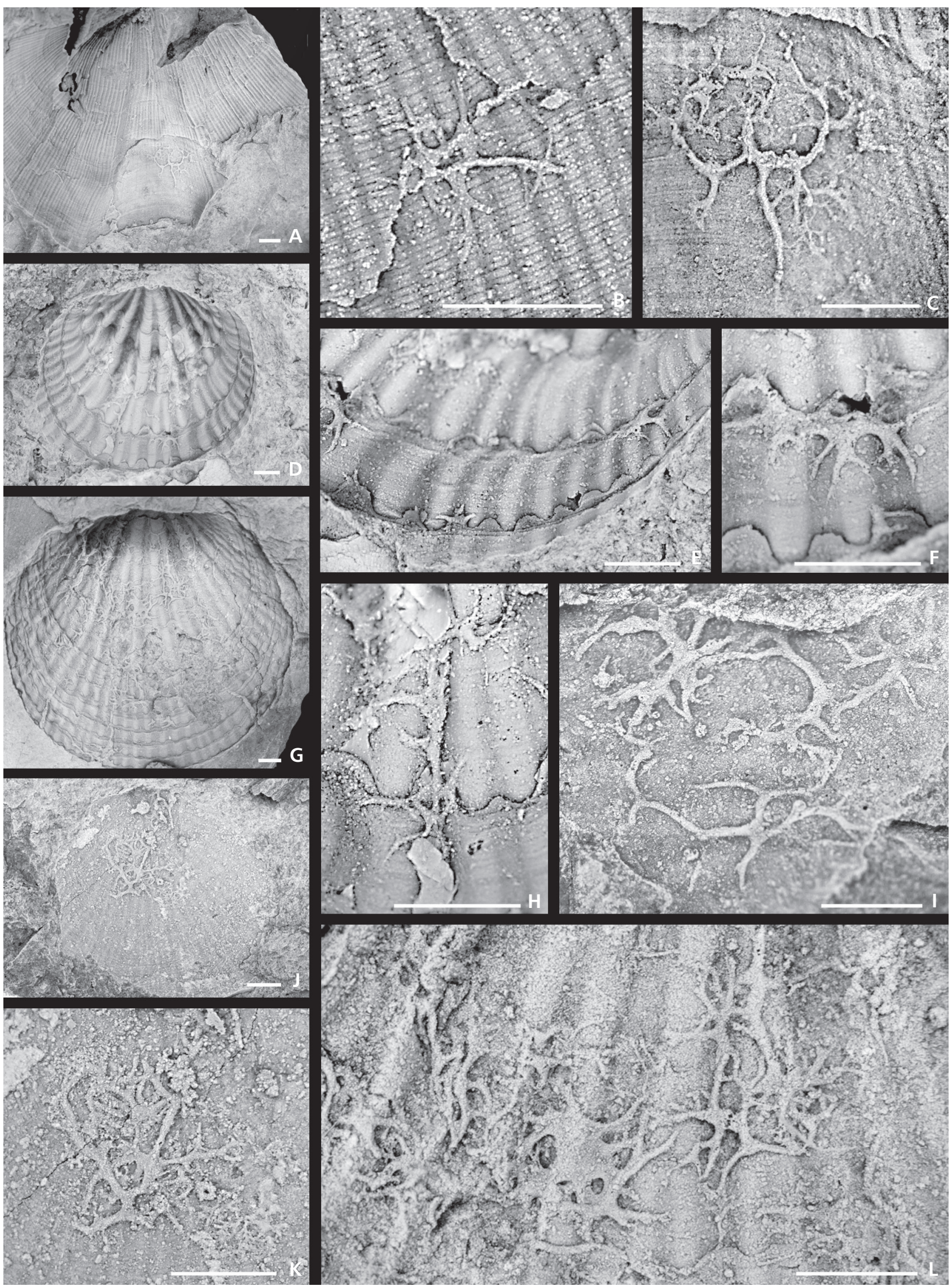


branch extends from the node. Primary branch has a length of $3-4 \mathrm{~mm}$ and is almost uniform $70 \mu \mathrm{m}$ wide along its entire length. However, one specimen (Fig. 3A, D) shows a short second branch extending from the central node. The branches are weakly sinuous (Fig. 3E) to markedly meandering (Fig. 3B, F, H). The secondary branches are short, some of the same width as primary branches but others are thinner being only $30 \mu \mathrm{m}$ wide. The secondary branches diverge at high angles to almost perpendicularly and rarely branch into tertiary branches that are short and shallow (Fig. 3G). One moderate complex plexus with more diverging branches was observed. The plexus likely originate by fusion of three microborings evidenced by clustered globular central nodes (Fig. 3C).

Remarks. - This microboring differs from other ichnospecies of Clionolithes reviewed by Wisshak (2017) in its lack of a rosette-like shape. Instead, the microboring has a deep node from which arises a long, thin, evenly wide and in some parts remarkably meandering primary branch giving rise to sparse, short secondary and tertiary branches. The shape of the boring is similar to fungal microborings (Golubic et al. 1975) having globular structures and long filaments, but these are markedly smaller.

Occurrence. - Želkovice Formation, "V Jakubince” Valley between Hýskov and Železná villages (locality 1), where is common in tuffaceous shale.

\section{Ichnogenus Rhopalondendrina Wisshak, 2017}

Type ichnospecies. - Rhopalondendrina avis Wisshak, 2017; Lower Jurassic, Sinemurian to Pliensbachian, Adnet Formation; Austria.

\section{Rhopalondendrina jakubinka isp. nov. Figures 4, 5}

Types. - Holotype: Specimens PCZCU 2411, natural cast attached to the surface of an external mould of the orthid brachiopod Giraldibella hyskovensis Havlíček, 1977, illustrated here as Fig. 5G.

Paratypes: Specimen PCZCU 2408, natural casts attached to the surface of an external mould of the athyridid brachiopod Hindella sp., illustrated here as Fig. 5A, B, E; specimens PCZCU 2409 and PCZCU 2412, natural casts attached to the surface of an internal mould of the pentamerid brachiopod Stricklandia sp., illustrated here as Fig. 5C, F, I-K; specimen PCZCU 2410, natural cast attached to the surface of an external mould of the orthid brachiopod Visbyella sp., illustrated here as Fig. $5 \mathrm{D}, \mathrm{H}$.

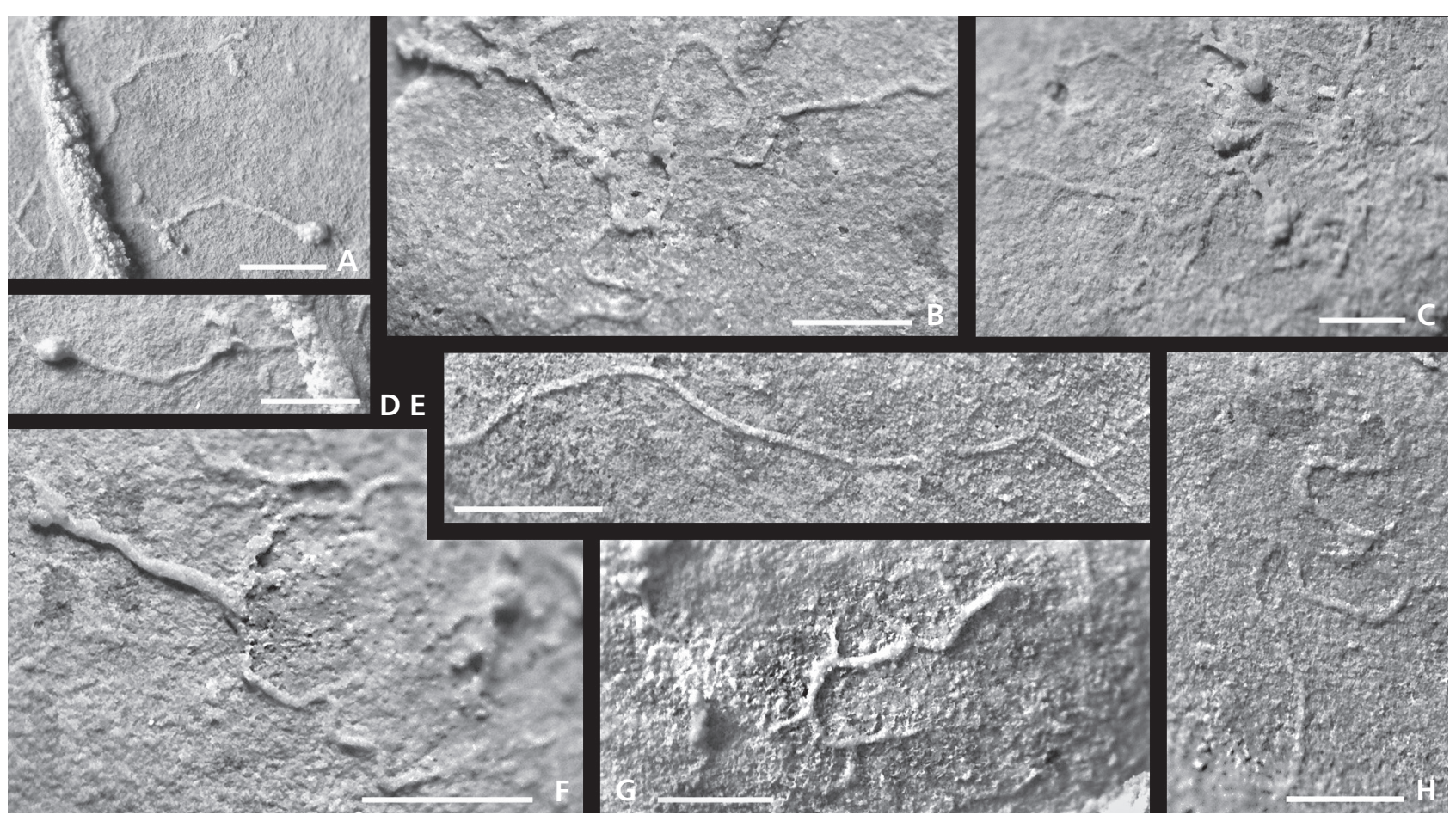

Figure 3. ? Clionolithes isp. Želkovice Formation, Hýskov; A-D, F-H - PCZCU 2415c, a long curved and branched primary branch with initial node (A, D), another initial node with extending straight primary branch with meandering branches (F), small plexus with three initial nodes (C), meandering distal branches (B, H), and meandering branch with secondary and tertiary branches (G) on internal surface of ventral valve of Hindella sp.; E - PCZCU 2409-, long straight branch on exterior of shell Stricklandia sp. All specimens are uncoated. Scale bars equal to $500 \mu \mathrm{m}$. 


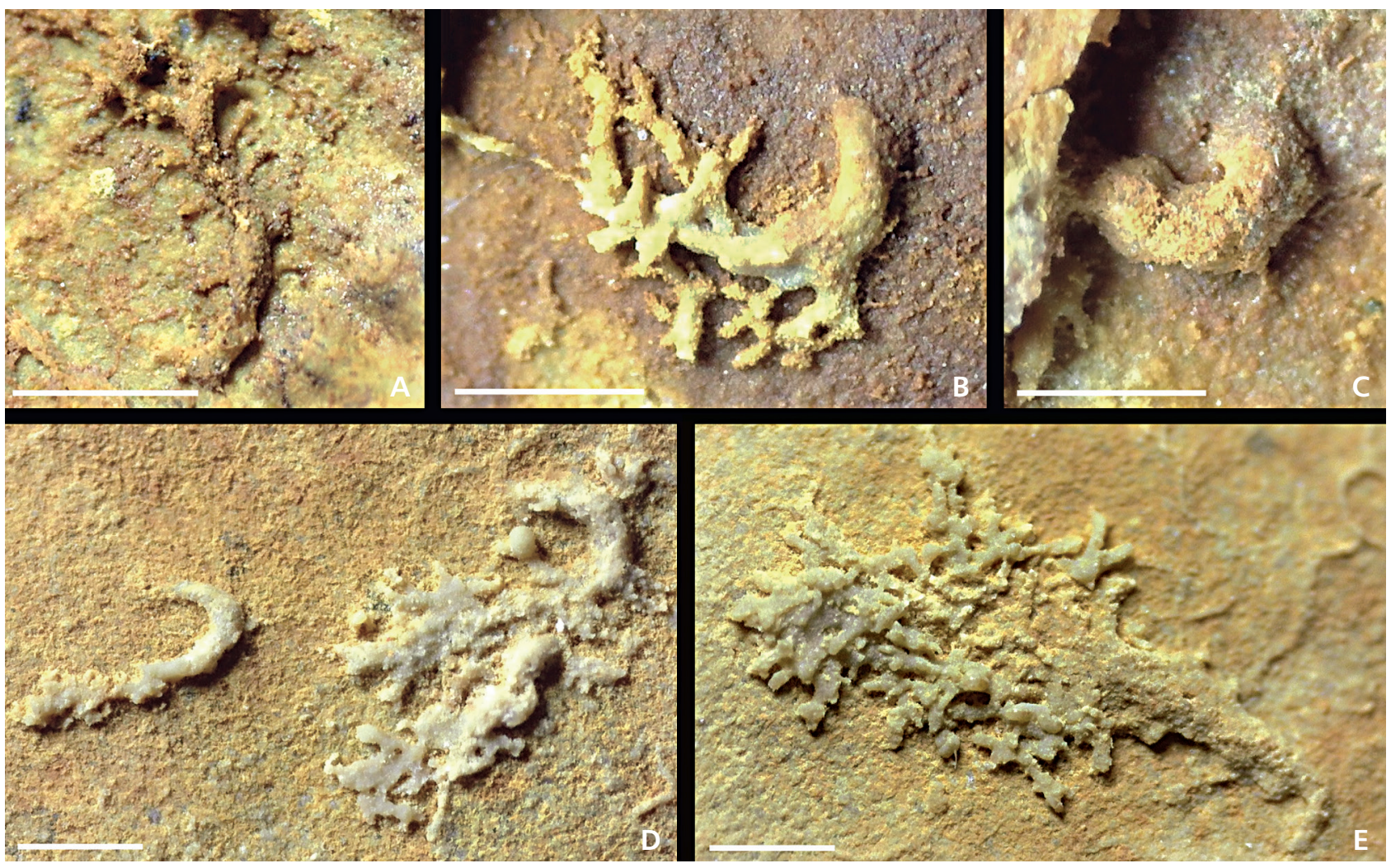

Figure 4. Rhopalondendrina jakubinka isp. nov. Želkovice Formation, Hýskov; A - PCZCU 2413, natural cast of small entrance tunnel with thin secondary tunnels on exterior of Giraldibella hyskovensis; B - PCZCU 2414a, natural cast of small microboring with C-shaped entrance tunnel on shell of Stricklandia sp.; C - PCZCU 2414b, natural casts of with broad C-shaped entrance tunnel on shell exterior of Stricklandia sp.; D - PCZCU 2415a, two natural casts of small microborings with C-shaped entrance tunnels on internal surface of shell of Hindella sp.; E - PCZCU 2415b, natural mould of medium sized microboring with straight entrance tunnel and plexus of short tunnels on internal surface of shell of Hindella sp. All specimens are uncoated. Scale bars equal to $500 \mu \mathrm{m}$.

Type horizon and locality. - Silurian, Aeronian, Želkovice Formation, Lobograptus scanicus/Saetograptus chimaera graptolite Biozone; "V Jakubince" Valley between Hýskov and Železná villages, Central Bohemia.

Material. - Seven shale slabs with brachiopod shells and trilobite pygidia, in total some 60 natural casts of microborings; figured specimens PCZCU 2408-2413, PCZCU 2414a, b, and PCZCU 2415a, b.

Etymology. - Based on local name of the type locality "V Jakubince".

Diagnosis. - Plexus elongate to subcircular, with imperfect bilateral symmetry. Entrance tunnel broad, oblique, C- or $\mathrm{S}$ - shaped, leading to laterally branching to anastomosing plexus. Branches are short, rhizoid-like with constant width and have a smooth texture. Thin secondary branches with apertures are aligned along initial part of the entrance tunnel.

Description. - Overall shape is unevenly bilaterally symmetrical with dome-shaped vertical profile. Entrance tunnel is tubular, oblique, forming the deepest part of microboring, usually $\mathrm{C}$ - or S-curved and subparallel to the surface of the host shell (Fig. 4B-D). The width of the tunnel is mostly 200 to $500 \mu \mathrm{m}$ (Fig. 5C, I) but the initial microboring may have a much thinner tunnel $(120 \mu \mathrm{m})$. The tunnel continues into a subplanar plexus (Fig. 5C), which is subcircular and 1.2 to $1.5 \mathrm{~mm}$ in size. Branching pattern varies from lateral (Fig. 5I), digitate (Fig. 5H) to anastomosing (Fig. 5C), with galleries of even width and likely smooth texture, but the finest details are obscured by the granularity of natural casts. The primary branches divide into short, curved rhizoid-like tunnels (Fig. 5E). Width of the primary branches ranges from 70 to $80 \mu \mathrm{m}$, but the primary branches of the plexus may be significantly larger. Thinner lateral galleries extend laterally at almost right angles to the entrance tunnel and the first formed gallery (Fig. 4A). These very thin galleries are more than $30 \mu \mathrm{m}$ wide and terminate at about $100 \mu \mathrm{m}$ distance from the main tunnel where likely they opened through a small aperture on the shell surface (Fig. 4A).

Remarks. - This species is referred to Rhopalondendrina 


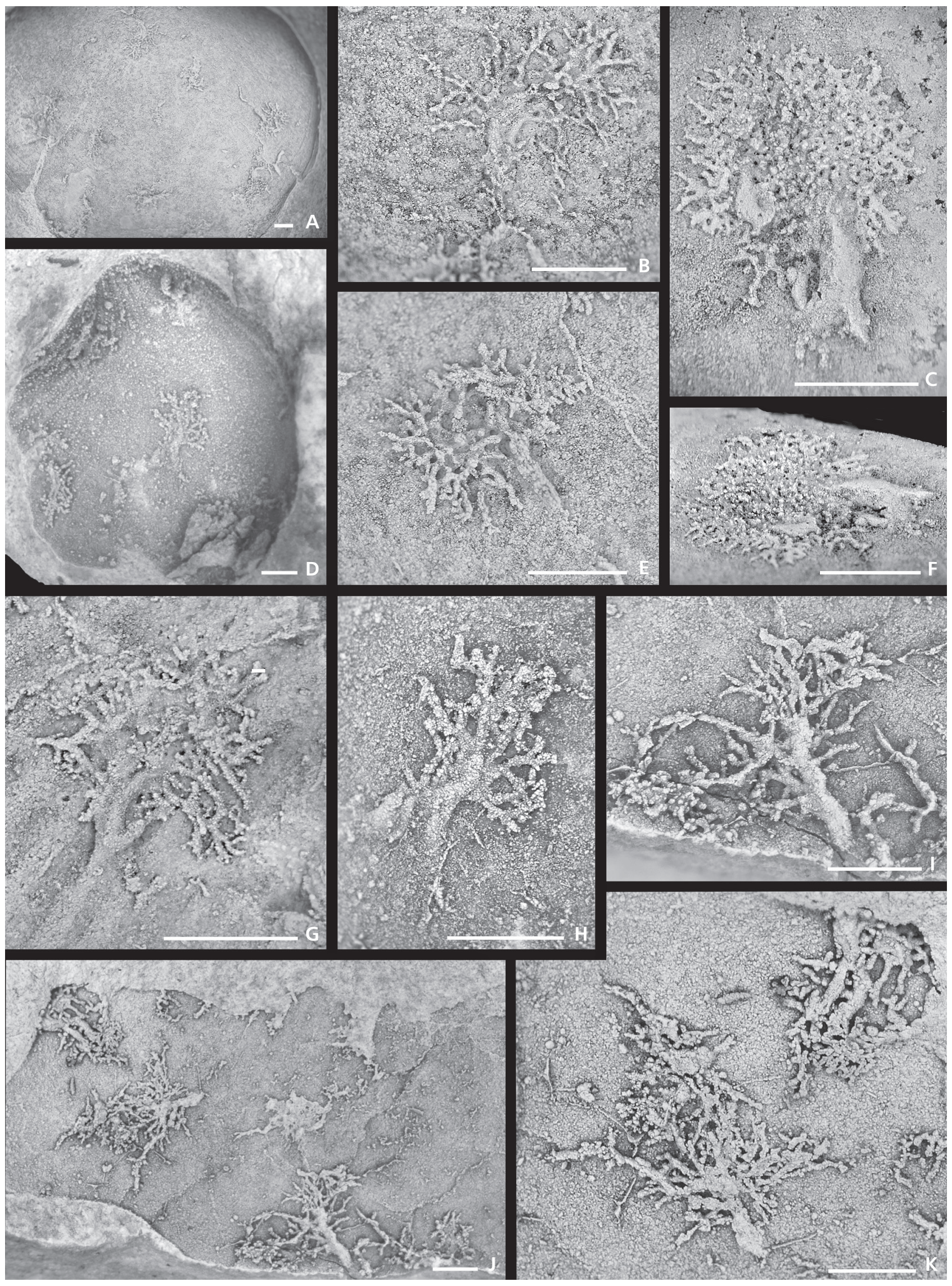




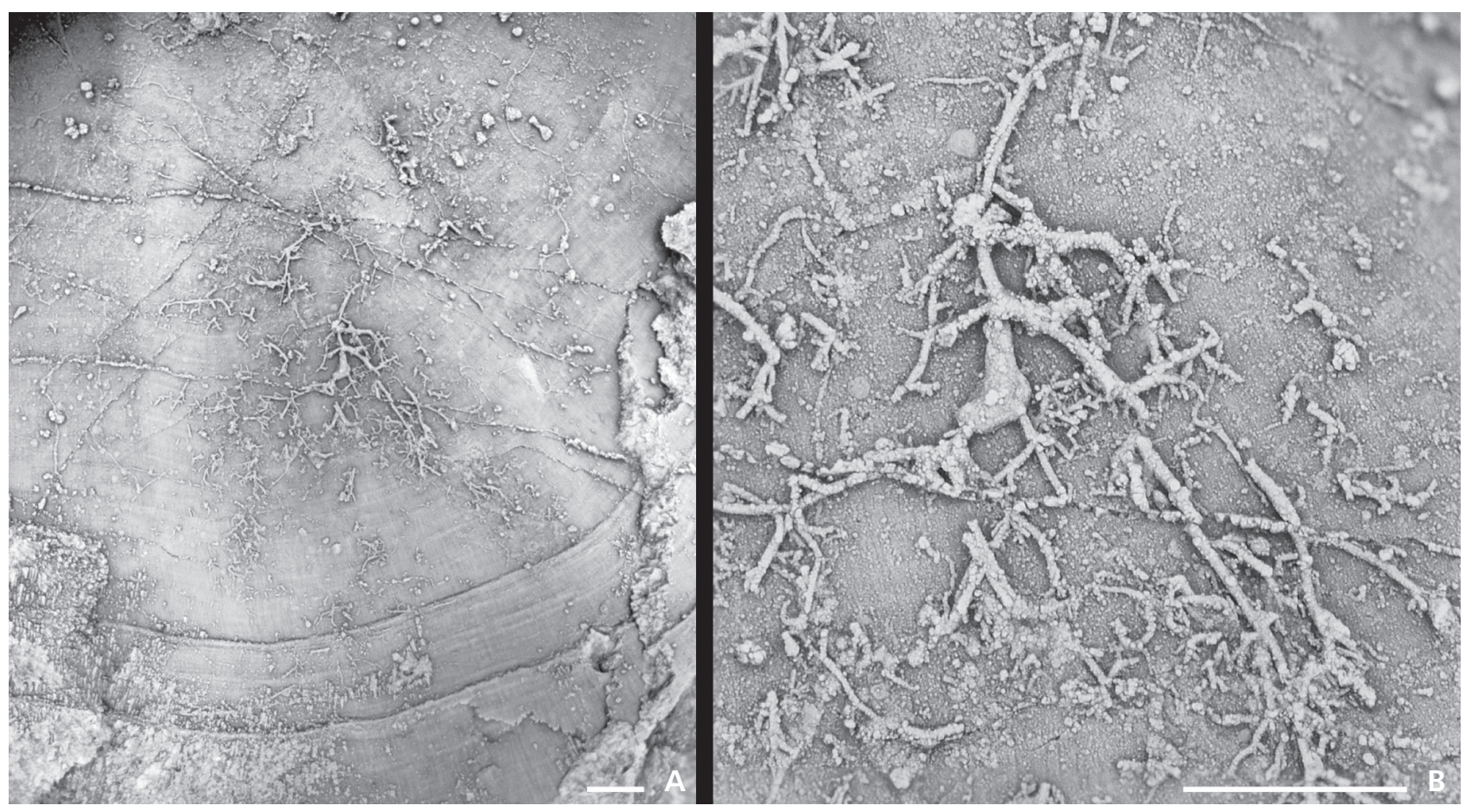

Figure 6. Dendrinid isp. indet. A, Želkovice Formation, Hýskov; A, B - PCZCU 2416, external mould of shell of Triplesia eospiriferoides with natural cast of microboring (A), and detail of the largest plexus (B). Scale bars equal to $1 \mathrm{~mm}$.

Wisshak, 2017 because of the distinct curved entrance tunnel which continues into a ramifying or anastomosing plexus. The previously oldest record of this ichnogenus is known in the Triassic, with more abundant occurrences in the Jurassic and Cenozoic. Apart from Rhopalondendrina contra Wisshak, 2017 from the Miocene of Victoria, Australia, all other species show sparser branching and their entrance tunnels are narrower and smaller than the tunnel of $R$. jakubinka isp. nov. The Miocene species $R$. contra shows distinct galleries and an arborescent plexus with a high degree of anastomosis and fusions. This feature is observed in $R$. jakubinka but the Silurian ichnospecies differs in its three-dimensional plexus and distinctly larger entrance tunnel.

\section{Dendrinid isp. indet.}

Figure 6

Material. - Natural cast on the external mould of Triplesia eospiriferoides Havlíček, 1990 in Havlíček \& Štorch (1990), (PCZCU 2416).
Description. - Plexus of galleries starts from a large pyriform entrance cavity, from which long, straight, and gently curved branches extend in all directions. The size of the plexus is about $10 \mathrm{~mm}^{2}$. Lateral branching is scarce with a divergence angle generally of $60^{\circ}$. Galleries are rounded in cross section, almost uniformly wide along their entire length, and 70-50 $\mu \mathrm{m}$ in diameter. These galleries never fuse when crossing; instead one gallery is located below the other. Thinner galleries, about $10-20 \mu \mathrm{m}$ wide, extend from the distal parts of the primary galleries (Fig. 6B, upper left and lower right corners). These terminal galleries are rhizoidal, forming a small dense ramiform plexus.

Remarks. - This microboring differs from Rhopalondendrina jakubinka isp. nov. from the same locality by having fewer branches in the plexus, larger size and in the absence of a distinct entrance tunnel. The dendrinid Clionolithes Clarke, 1908 differs from this unnamed dendrinid in the rosette shape of microboring.

Occurrence. - Želkovice Formation, "V Jakubince” Valley

Figure 5. Rhopalondendrina jakubinka isp. nov. Želkovice Formation, Hýskov; A, B, E - PCZCU 2408, external mould of shell of Hindella sp. with eight natural casts (A), and (B, E) detail of two of them; C, F - PCZCU 2409, internal mould of shell of Stricklandia sp. with natural cast (C) showing broad entrance tunnel and large anastomoses in plexus, and (F) the same specimen in oblique view; D, H - PCZCU 2410, external mould of shell of Visbyella sp. (D) with (H) a natural cast showing small plexus; G - PCZCU 2411, the holotype, external mould of shell of Giraldibella hyskovensis with natural cast showing entrance tunnel; I-K - PCZCU 2412, external mould of shell of Stricklandia sp. with several dendritic natural casts (J), and (I, K) detail of two of them. All specimens are coated by ammonium chloride. Scale bars equal to $1 \mathrm{~mm}$. 
between Hýskov and Železná villages (locality 1), where it is rare in tuffaceous limestones above the beds with Rhopalondendrina jakubinka isp. nov.

\section{Discussion}

\section{Taphonomic limits of dendrinid occurrences in the Barrandian area}

Observations by numerous workers (Hurst 1974, Kesling et al. 1980, Sparks et al. 1980, Lebold 2000, Lescinsky et al. 2002, Mistiaen et al. 2012, Furlong \& McRoberts 2014) have shown, that, at least in some instances, sclerobiont encrustations and endobiont microborings occurred while the host was alive. The host was by some way affected by sclero- or endobionts (e.g. by stoppage or alternation of growth), or sclero- and endobiont settlements were related to life processes of the hosts (life position or location of inhalation currents on of host etc.).

Smrecak \& Brett (2014) in their review of taphonomic processes affecting the frequency of encrustation of host shells by sclerobionts suggested that the most important is the burial and exhumation of host shells. A chance for encrustation or microboring will occur only when the surface of dead shell is exposed for some time interval on a sea floor. Tomašových et al. (2006) showed that shellrich and relatively unaltered horizons of rapidly buried shells have fewer encrusted and bioeroded shells than horizons with less common shells but with presumably longer exposure times of sea floor. Unburied and shallowly buried shells encounter more opportunities for bioerosion and taphonomic damage (Davies et al. 1989, Tomašových \& Zuschin 2009, Smrecak \& Brett 2014). Shell size was found to be another important limiting factor in encrustation and bioerosion (Lescinsky et al. 2002, Rodland et al. 2004, Mistiaen et al. 2012). Smrecak \& Brett (2014) suggested that sclerobionts provide more sensitive palaeoecological indicator for relative depth than do microendobionts.

Up to now, dendritic microborings have not been described on shells from the Silurian strata in the Barrandian area, despite more than 170 years of study. This discrepancy could be explained by the simple overlooking of these microboring traces during sampling. However, it seems more probable that their rarity is real. This indicates that levels of infestation by dendritic endobionts demanded a proper ecological niche and adequate time interval. In addition, the preservation of microborings involved also favourable sedimentary and taphonomic processes. Both conditions were rarely met in the Barrandian area, at least in the shell beds which are regular sources of fossils for collectors.

\section{Alive host or dead shell?}

Criteria for inferring of living or dead hosts of sclerobionts and their relative strengths were summarized by Taylor \& Wilson (2003). In living brachiopods the punctae of the shell may deter or preclude encrustation and endolithic microboring (Palmer \& Fürsich 1974, Thayer 1974, Bordeaux \& Brett 1990, Alexander \& Scharpf 1990). Theoretically, this criterion could help to distinguish alive or dead brachiopod host. However, the morphology and the function of punctae in the Lower Palaeozoic dalmanellidines differ from these of the Recent relatives (Williams 1997). The observations of other authors (Mistiaen et al. 2012) confirm a weak significance of punctation to infestation of sclero- and endobionts in the Lower Palaeozoic. Hence, this criterion is useless in studied material, because described borings are present in species having impunctate shells.

The empty shells of dead brachiopods exposed on the sea floor represent an ideal substrate for the settlement of the larval stage of endobionts: shells were calcareous in composition and they were large, thick-walled and heavy enough to stay at the same place for a long time interval. The time lag between the death of the brachiopod and the settlement of the endobiont onto an empty shell was sufficient to allow the disarticulation of the shell (e.g. by the activity of scavengers or weak water movements) and to change its position on the sea floor (e.g. convexup attitude of the shell, semiburial of the shell or wedge of the shell between other objects). The disarticulation of brachiopod shells by breakage in rough currents of agitated shallow environments would produce rounded fragments and worn shell surfaces, but samples with dendritic microborings from the Želkovice and Kopanina formations show no traces of abrasive processes on shells.

Clionolithes amoebae probably infested empty shells, but definitive evidence is limited by the number of shells in the studied sample. Microborings were never observed on the interiors of the shell, while the exteriors may be heavily bored, sometimes with several microborings in close contact (Fig. 2G, L). The microboring often started in a sheltered part of the shell, e.g. in a crevices below concentric lamellae (Fig. 2E, F). Depths of microborings are small, and they are distinctly clustered on elevated parts of convex shells. Branches of the microborings never penetrate inside host shells. Previous observations (Clarke 1908, Wisshak 2017) confirm that atrypid brachiopods were common hosts of Clionolithes. The most complex plexus of Clionolithes amoebae was observed in the dorsal valve of Kantinatrypa (Fig. 2G), but the ventral valves (not figured here) show similar densities of microborings. Many Silurian atrypids with comparable biconvex shells had a fixosessile mode of life. Their shell likely had a subvertical orientation on muddy substrates (Copper 2004). Consequently, the exterior 
of both valves of the living brachiopod was accessible for settlement of endobionts. Equal presence of microborings in both valves and the apical sector is suggestive of endobiont settlement onto disarticulated shells. A stable convex-up position of empty shells on the sea floor facilitates infestation at the highest points of convex part of the valve. The shell interior was not accessible for settlement of a larva. If the Clionolithes endobiont was a sponge that accommodated phototrophic symbionts, its growth would be limited by the deficiency of light inside the concave surface when the valve was in a convex-up attitude. Other Clionolithes endobionts attached to the dorsal shell of the eospiriferid Cyrtia bedya (Fig. 2A-C) are accompanied by a cornulitid tubeworm on the external shell surface. The opening of this cornulitid faces posterolaterally toward the hinge line of the valve. This orientation is unusual for cornulitids. Those in which the tubes were attached to living hosts regularly have the open end towards the commissure and anterior margin (Richards 1974, Sparks et al. 1980, Zhan \& Vinn 2007). Although unique in the sample, this cornulitid tube supports the suggestion that the host Cyrtia bedya was already dead when the cornulitid tubeworm and Clionolithes endobionts settled onto its shell.

Rhopalondendrina jakubinka and ? Clionolithes isp. lived primarily on dead shells. The majority of the former show that the entrance tunnels opened on the outer surfaces of host shells, but many microborings also opened on the inner surfaces of the same shells (the ratio of microborings observed on outer:inner surface of host shells is 36:26). Microborings on inner surfaces of host shells could develop only in dead brachiopods because the mantle epithelium was in direct contact with an inner surface of the shell when the brachiopods were alive. Selectivity of the endobiont is evident from preferential infestation of large shells (Stricklandia), thick to medium-thick shells (Hindella), and shells with ribbed surfaces (Giraldibella, Visbyella). Associated smaller and thin-walled brachiopods (Saukrodictya, Aegironetes) are not infested. The calcitic skeleton of the heavy-shelled trilobite Encrinuraspis mareki was rarely used as substrate for the endobionts. The microborings observed in trilobite pygidia of this species are much smaller and shallower than those on associated brachiopod shells, suggesting that brachiopod shells were better substrates. The level of infestation of hosts by $R$. jakubinka was enormous in the type locality. There are up to 10 microborings per $1 \mathrm{~cm}^{2}$ of shell surface. Almost all larger and thicker shell fragments bear traces of endobiont activity; one valve of Hindella displays 10 microborings on the outer surface and two microborings on the inner surface. The inner surface of another valve of the same species shows 18 smaller microborings of R. jakubinka; unfortunately, the external mould of this valve is not preserved. Traces of $R$. jakubinka are often associated with simple and shallower meandering shallow traces of
? Clionolithes isp., both on outer and inner surfaces of host shells. This confirms the post-mortem infestation of host shells by more than one species of endobiont.

\section{Diversity and depth limits of dendrinid endobionts in the Barrandian}

Although there is high level of shell infestation by dendrinids, their morphological uniformity in each locality indicates that they were produced by a particular endobiont. This contrasts with remarkably high diversity of dendrinid and other endobionts observed in Mesozoic belemnite guards (Wisshak 2017, Wisshak et al. 2017).

Depth of environments of both associations was likely within the photic zone. Smrecak \& Brett (2014) stated that sclerobionts are fewer in the dysphotic zone, with a decrease in abundance and diversity from shallow euphotic to deep euphotic zones. With the exception of heterotrophic fungi (Golubic et al. 1975), the same suggestion could apply to large heterotrophic endobionts. Observations in the last few decades (e.g. Ziegler 1965; Boucot 1975; Brett et al. 1993; Watkins 1979, 2000; Copper 2004) have indicated that brachiopod associations provide reliable data for estimation of depth and spatial distribution along onshore-offshore transects. Brachiopods associated with Rhopalondedrina jakubinka and ? Clionolithes isp. in the Želkovice Formation indicate an environment in the deep euphotic to dysphotic zone. This is based on the presence of the large pentamerid Stricklandia sp. which is a characteristic genus of deeper subtidal brachiopod associations BA 4 to BA5 (Ziegler et al. 1968, Boucot 1975). Associated small-sized plectambonitoids, orthids (Saukrodictya, Giraldibella, Dicoelosia) and the protorthid Skenidnoides confirm a deeper environment (Boucot 1975).

Following Havlíček \& Štorch (1990), it is suggested that the moderately diverse association with dominant Leptostrophiella nebulosa of the Kopanina Formation occupied a shallower environment in the euphotic zone. This is confirmed by the generally higher diversity and taxonomic composition of the brachiopods. The presence of atrypids, Leptostrophiella, Janius and abundance of the eospirifer Cyrtia indicate that environment suitable for the endobiont Clionolithes amoebae was somewhat shallower than that for Rhopalondendrina jakubinka.

\section{Conclusion}

Four types of dendritic microborings have been found on brachiopod shells in two stratigraphic levels of the Silurian in the Barrandian: the dendrinids Rhopalondendrina jakubinka isp. nov., ? Clionolithes isp. and unnamed ichnospecies are of Llandovery (Aeronian) age, and Clio- 
nolithes amoebae isp. nov. is of Ludlow (Gorstian) age. Rhopalondendrina jakubinka forms a dense plexus of thin rhizoidal tunnels extending from a broad entrance tunnel. ? Clionolithes isp. is characteristic by sparsely branching thin branches with a globular central node, while C. amoebae forms a rosette-like microboring with sinusoid primary branches and scarce lateral branches of smaller size. Hence, C. amoebae is more similar to stratigraphically younger rosetted endoborings. All ichnospecies represent one of the earliest reports of dendritic microborings in brachiopod shells.

Both associations indicate a high level of utilization of dead bioskeletal material on the sea floor by the boring endobionts. Shells were exposed on weakly agitated sea floor for longer time interval and they were not affected by mechanical abrasion. This indicates a narrow ecological niche of endobionts, most likely within the deeper euphotic zone. Biotic and taphonomic conditions (size selectivity of host shell, surface selectivity of host shell, time of exposure of shells on the sea floor) observed in both Bohemian occurrences are consistent with biotic and taphonomic observations of bioencrustation and bioerosion processes elsewhere in the Palaeozoic (Mistiaen et al. 2012, Smrecak \& Brett 2014, Furlong \& McRoberts 2014).

\section{Acknowledgments}

The author is grateful to Paul Taylor, Natural History Museum, London, and to Olev Vinn, University of Tartu, for constructive reviews. The research was supported by the Czech Science Foundation, project GA18-05935S (From past to present: fossil $v s$. recent marine shelled organisms as a substrate for colonization and bioerosion).

\section{References}

Alexander, R.R. \& Scharpf, C.D. 1990. Epizoans on Late Ordovician brachiopods from southeastern Indiana. Historical Biology 4, 179-202. DOI 10.1080/08912969009386542

BARRANDE, J. 1846. Notice préliminaire sur le Système Silurien du Centre de la Bohême. 97 pp. Leipzig.

DOI 10.5962/bhl.title.9142

BARRANDE, J. 1848. Ueber die Brachiopoden der silurischen Schichten von Böhmen. II. Teil. Naturwissenschaftliche Abhandlungen 2, W. Haidinger. Wien, 155-256.

Barrande, J. 1852. Système Silurien du Centre de la Bohême, Ière Partie, Crustacès, Trilobites. 2 vols. 935 pp. Prague \& Paris. DOI 10.5962/bhl.title.14776

Barrande, J. 1879. Systême silurien du centre de la Bohême. Iére partie. Recherches paléontologiques. Vol. 5. Classe des Mollusques. Ordre des Brachiopodes. 226 pp. Prague \& Paris.
Bordeaux, Y.L. \& Brett, C.E. 1990. Medium specific associations of epibionts on Middle Devonian brachiopods: implication for paleoecology. Historical Biology 4, 203-220. DOI 0.1080/08912969009386543

Boucot, A.J. 1975. Evolution and extinction rate controls. 427 pp. Elsevier.

Brett, C.E.., Boucot, A.J. \& Jones, B. 1993. Absolute depths of Silurian benthic assemblages. Lethaia 26, 25-40. DOI 10.1111/j.1502-3931.1993.tb01507.x

Bromley, R.G., Wisshak, M., Glaub, I. \& \& Botquelen, A. 2007. Ichnotaxonomic review of dendriniform borings attributed to foraminiferans: Semidendrina igen. nov., 518-530. In Miller III, W. (ed.) Trace Fossil: Concepts, Problems, Prospects. Elsevier Science, Amsterdam.

DOI 10.1016/B978-044452949-7/50158-3

Clarke, J.M. 1908. The beginning of dependent life. New York State Museum Bulletin 121, 146-169.

Clarke, J.M. 1921. Organic dependence and disease, their origin and significance. New York State Museum Bulletin 221-222, 1-113. DOI 10.5962/bhl.title.19803

CopPer, P. 2004. Silurian (Late Llandovery-Ludlow) atrypid brachiopods from Gotland, Sweden, and the Welsh Borderlands, Great Britain. 215 pp. NRC Researh Press, Ottawa, Ontario. DOI 10.1139/9780660190112

Davies, D.J., Powell, E.N. \& Stanton, R.J., JR. 1989. Taphonomic signature as a function of environmental process: Shells and shell beds in a hurricane influenced inlet on the Texas coast. Palaeogeography, Palaeoclimatology, Palaeoecology 72, 317-356. DOI 10.1016/0031-0182(89)90150-8

DuFKA, P. 1990. Acritarchs of the Monograptus sedgwickii Zone (Želkovice Formation, Llandovery) from Hýskov, Barrandian, Bohemian Massif. Acta Universitatis Carolinae, Geologica 1990(1), 75-104.

DufKa, P. 1992. Lower Silurian Chitinozoans of the Prague Basin (Barrandian, Czechoslovakia). Revue de Micropaléontologie 35(2), 117-126.

Fenton, C.L. \& Fenton, M.A. 1932. Boring sponges in the Devonian of Iowa. American Midland Naturalist 13, 42-54. DOI 10.2307/2419951

Furlong, C.M. \& McRoberts, C.A. 2014. Commensal borings from the Middle Devonian of Central New York: Ecologic and taphonomic review of Clionoides, Clionolithes, and Canaliparva $\mathrm{n}$. ichnogen. Journal of Paleontology 88, 130-144. DOI 10.1666/12-141

Golubic, S., Perkins, R.D. \& Lukas, K.J. 1975. Boring microorganisms and microborings in carbonate substrate, 229-259. In FreY, R.W. (ed.) The study of trace fossils. Springer-Verlag, Berlin-Heidelberg. DOI 10.1007/978-3-642-65923-2 12

HavlíčEK, V. 1977. Brachiopods of the order Orthida in Czechoslovakia. Rozpravy Ústredního ústavu geologického 44, 1-327.

HavlíčEK, V. 1980. New Eospiriferinae (Brachiopoda) in Bohemia. Sborník geologických věd, Paleontologie 23, 7-48.

HAvLíčEK, V. 1995. New data on the distribution of brachiopods in the Motol and lowest Kopanina Formations (Wenlock, lower Ludlow, Prague Basin, Bohemia). Věstník Ústředního ústavu geologického 70, 47-63. 
HavlíčEK, V. \& KŘíž, J. 1973. Svrchní llandover a spodní devon u Hýskova (Barrandien). Věstník Ústředního ústavu geologického 48, 103-107.

HAVLíčEK, V. \& ŠTORCH, P. 1990. Silurian brachiopods and benthic communities in the Prague Basin (Czechoslovakia). Rozpravy Ústředního ústavu geologického 48, 1-275.

Hofmann, K. 1996. Die mikro-endolithischen Spirenfossilien der borealen Oberkreide Nordwest-Europas und ihre Faciesbeziehungen. Geologisches Jahrbuch, Serie A 136, 1-151.

Hurst, J.M. 1974. Selective epizoan encrustation of some Silurian brachiopods from Gotland. Palaeontology 17, 423-429.

JAEGER, H. 1991. Neue Standard-Graptolithenzonenfolge nach der "Grossen Krise" and der Wenlock/Ludlow-Grenze (Silurian). Neues Jahrbuch für Geologie und Paläontologie, Abhandlungen 182(3), 303-354.

DOI 10.1127/njgpa/182/1991/303

Kesling, R.V., Hoare, R.D. \& Sparks, D.K. 1980. Epizoans of the Middle Devonian brachiopod Paraspirifer bownockeri: their relationships to one another and their host. Journal of Paleontology 54, 1141-1154.

KRAFT, J. 1982. Dendroid graptolites of Llandoverian age from Hýskov near Beroun (Barrandian). Sbornik geologických věd, Paleontologie 25, 83-95.

KŘiž, J. 1991. The Silurian of the Prague Basin (Bohemia) tectonic, eustatic and volcanic controls on facies and faunal development, 179-203. In Bassett, M.G., LAN, P.D. \& EDwards, D. (eds) The Murchison Symposium: proceedings of an international conference of the Silurian System. Special Papers Palaeontology 44.

KŘiž, J. 1992. Silurian field excursions: Prague Basin (Barrandian), Bohemia. National Museum Wales, Geological Series 13, 1-111.

Kříž, J. 1998. Silurian, 79-101. In Chlupáč, I., HavlíčEK, V., KŘíž, J., Kukal, Z. \& ŠTorch, P. (eds) Palaeozoic of the Barrandian. Czech Geological Survey. Prague.

Lebold, J.G. 2000. Quantitative analysis of epizoans on Silurian stromatoporoids within the Brassfield Formation. Journal of Paleontology 54, 1141-1154.

Lescinsky, H.L., Edinger, E. \& Risk, M.J. 2002. Mollusc shell encrustation and bioerosian rates in a modern epeiric sea: taphonomy experiments in the Java Sea, Indonesia. Palaios 17, 171-191.

DOI10.1669/0883-1351(2002)017<0171:MSEABR >2.0.CO;2

Loydell, D.K. 2012. Graptolite biozone correlation charts. Geological Magazine 149(1), 124-132.

DOI 10.1017/S0016756811000513

Mägdefrau, K. 1937. Lebensspuren fossiler "Bohr"-Organismen. Beiträge zur naturkundlichen Forschung in Südwestdeutschland 2, 54-67.

Mergl, M. 1999. Genus Paterula (Brachiopoda) in Ordovician-Silurian sequence of Central Bohemia. Věstnik Českého geologického ústavu 74, 347-361.

Mergl, M. 2001. Lingulate brachiopods of the Silurian and Devonian of the Barrandian. Acta Musei Nationalis Pragae, Series B-Historia naturalis 57, 1-49.

Mistiaen, B., Brice, D., Zapalski, M.K. \& Loones, C. 2012. Brachiopods and their auloporid epibionts in the Devonian of Boulonnais (France): Comparison with other associations globally, 159-189. In Talent, J.A. (ed.) Earth and Life. Global Biodiversity, Extinction Intervals and Biogeographic Perturbations Through Time.

DOI 10.1007/978-90-481-3428-1_7

Palmer, T.J. \& FÜrsich, F.T. 1974. The ecology of a Middle Jurassic hardground and crevice fauna. Palaeontology 17, 507-524.

Quenstedt, F.A. 1849. Petrefaktenkunde Deutschland, 1. Abteilung, 1 Band, Cephalopoden. 551 pp. Ludwig Friedrich Fues, Tübingen.

Richards, P.R. 1974. Ecology of Cornulitidae. Journal of Paleontology 48, 514-523.

Rodland, D.L., Kowalewski, M., Carrol, M. \& Simoes, M.G. 2004. Colonization of a "Lost World": encrustation patterns in modern subtropical brachiopod assemblages. Palaios 19, 381-395.

DOI10.1669/0883-1351(2004)019<0381:COALWE $>2.0 . C O ; 2$

SmrecaK, T.A. \& Brett, C.E. 2014. Establishing patterns in sclerobiont distribution in a late Ordovician (Cincinnatian) depth gradient: toward a sclerobiofacies model. Palaios 29, 74-85. DOI 10.2110/palo.2012.128

$\breve{S}_{\text {NAJDR, M. }}$ 1975. New Trilobita from the Llandovery at Hýskov in the Beroun area, Central Bohemia. Věstník Českého geologického ústavu 50, 311-316.

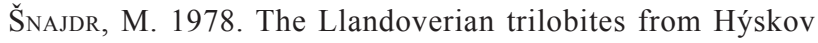
(Barrandian area). Sborník geologických věd, Paleontologie 21, 7-47.

Solle, G. 1938. Die ersten Bohr-Spongien im europäischen Devon und einige andere Spuren. Senckenbergiana Lethaea 20, 154-178.

Sparks, D.K., Hoare, R.D. \& Kesling, R.V. 1980. Epizoans on the brachiopod Paraspirifer bownockeri (Stewart) from the Middle Devonian of Ohio. Papers on Paleontology 23, 1-105.

ŠToRCH, P. 2001.Graptolites, stratigraphy and depositional setting of the middle Llandovery (Silurian) volcanocarbonate facies at Hýskov (Barrandian area, Czech Republic). Bulletin of Geosciences 76, 55-62.

Talent, J.A. 1963. The Devonian of the Mitchell and Wentworth Rivers. Geological Survey of Victoria, Memoir 24, 1-118.

TAPANILA, L. 2008. The medium is the message: imaging a complex microboring (Pyrodendrina cupra igen. n., isp. n.) from the early Paleozoic of Anticosti Island, Canada, 123-145. In WisshaK, M. \& Tapanila, L. (eds) Current Development of Bioerosion. Springer, Heidelberg. DOI 10.1007/978-3-540-77598-0_7

TAYLOR, P.D. \& WILSON, M.A. 2003. Palaeoecology and evolution of marine hard substrate communities. Earth-Science Reviews 62, 1-103. DOI 10.1016/S0012-8252(02)00131-9

Thayer, C.W. 1974. Substrate specificity of Devonian epizoa. Journal of Paleontology 48, 881-894.

TomašovÝch, A. \& Zuschin, M. 2009. Variation in brachiopod preservation along a carbonate shelf-basin transect (Red Sea and Gulf of Aden): environmental sensitivity of taphofacies. Palaios 24, 697-716. DOI 10.2110/palo.2009.p09-018r

Tomašových, A., Fürsich, F.T. \& Olszewski, T.D. 2006. 
Modeling shelliness and alteration in shell beds: variation in hardpart imput and burial rates leads to opposing predictions. Paleobiology 32, 278-298.

DOI 10.1666/0094-8373(2006)32[278:MSAAIS]2.0.CO;2

Tonarová, P., VodrážKovÁ, S., Hints, O., MÄnNik, P., KubajKo, M. \& FRÝDA, J. 2019. Llandovery microfossils and microfacies of the Hýskov section, Prague Basin. Fossil Imprint 75(1), 25-43. DOI 10.2478/if-2019-0002

Toom, U., Vinn, O. \& Hints, O. 2019. Ordovician and Silurian ichnofossils from carbonate facies in Estonia: A collectionbased review. Palaeoworld 28, 123-144.

DOI 10.1016/j.palwor.2018.07.001

Vogel, K. \& BRetT, C.E. 2009. Record of microendoliths in different facies of the Upper Ordovician in the Cincinnati Arch region USA: The early history of light-related microendolithic zonation. Palaeogeography, Palaeoclimatology, Palaeoecology 281, 1-24.

DOI 10.1016/j.palaeo.2009.06.032

Vogel, K., Golubic, S. \& Brett, C.E. 1987. Endolith association and their relation to facies distribution in the Middle Devonian of New York State, USA. Lethaia 20, 263-290.

DOI 10.1111/j.1502-3931.1987.tb00787.x

WATKINS, R. 1979 Benthic commuity organization in the Ludlow Series of the Welsh Borderland. Bulletin of the British Museum, Natural History 31, 175-280.
WatKIns, R. 2000. Silurian reef-dwelling brachiopods and their ecologic implications. Palaios 15, 112-119. DOI10.1669/0883-1351(2000)015<0112:SRDBAT $>2.0 . C O ; 2$

Williams, A. 1997. Shell structure, 267-320. In Williams, A., Brunton, C.H.C. \& CARLson, S.J. et al. (eds) Treatise on Invertebrate Paleontology, part H, Brachiopoda, Revised, Volume 2. Geological Society of America Inc. and The University of Kansas, Boulder, Lawrence.

WisshaK, M. 2017. Taming an ichnotaxonomical Pandora's box: revision of dendritic and rosetted microborings (ichnofamily: Dendrinidae). European Journal of Taxonomy 390, 1-99. DOI 10.5852/ejt.2017.390

WisshaK, M., Titschack, J., Kahl, W. \& Girod, P. 2017. Classical and new bioerosion trace fossils in Cretaceous belemnite guards characterised via micro-CT. Fossil Record 20, 173-199. DOI 10.5194/fr-20-173-2017

ZHAN, R.B. \& VINN, O. 2007. Cornulitid epibionts on brachiopod shells from the Late Ordovician (middle Ashgill) of East China. Estonian Journal of Earth Sciences 56, 101-108.

ZIEGLER, A.M. 1965. Silurian marine communities and their environmental significance. Nature 207, 270-272. DOI 10.1038/207270a0

Ziegler, A.M., Cocks, L.R.M. \& BAMBACH, R.K. 1968. The composition and structure of Lower Silurian marine communities. Lethaia 1, 1-27. DOI 10.1111/j.1502-3931.1968.tb01724.x 